\title{
ANATOMY AND DRYING OF WOOD OF FOUR SPECIES FROM AN AGROFORESTRY SYSTEM
}

\author{
Elder Eloy ${ }^{1 *}$, Rômulo Trevisan ${ }^{2}$, Tainara dos Santos Piecha ${ }^{3}$, Magda Rosa Fontoura ${ }^{4}$, Henrique Webber Dalla \\ Costa $^{5}$, Braulio Otomar Caron ${ }^{6}$ \\ ${ }^{1 *}$ Universidade Federal de Santa Maria, Departamento de Engenharia Florestal, Frederico Westphalen, RS, Brasil - \\ eloyelder@yahoo.com.br \\ ${ }^{2}$ Universidade Federal de Santa Maria, Departamento de Engenharia Florestal, Frederico Westphalen, RS, Brasil - \\ romulo_trevisan@yahoo.com.br \\ ${ }^{3}$ Universidade Federal de Santa Maria, Curso de Engenharia Florestal, Frederico Westphalen, RS, Brasil - tainarapiecha@gmail.com \\ ${ }^{4}$ Universidade Federal de Santa Maria, Curso de Engenharia Florestal, Frederico Westphalen, RS, Brasil - magdarosaf124@ gmail.com \\ ${ }^{5}$ Universidade Federal de Santa Maria, Programa de Pós-Graduação em Engenharia Florestal, Santa Maria, RS, Brasil - \\ hwdallacosta@gmail.com \\ ${ }^{6}$ Universidade Federal de Santa Maria, Departamento de Agronomia, Frederico Westphalen, RS, Brasil - otomarcaron@yahoo.com.br
}

Received for publication: 26/05/2020 - Accepted for publication: 18/08/2020

\begin{abstract}
Resumo
Anatomia e secagem da madeira de quatro espécies de um sistema agroflorestal. A secagem é um importante processo na geração de produtos de madeira aumentando a qualidade do produto final, mas é influenciada pelas características anatômicas. O presente estudo teve como objetivo avaliar a influência da anatomia na secagem da madeira de Parapiptadenia rigida (Benth.) Brenan, Peltophorum dubium (Spreng.) Taub., Eucalyptus grandis W. Hill $\times$ Eucalyptus urophylla S.T. Blake (híbrido) e Schizolobium parahyba (Vell.) Blake provenientes de um sistema agroflorestal. Foram amostradas três árvores de cada espécie, com a idade de 9 anos. Os corpos de prova foram retirados da região do diâmetro a altura do peito (DAP) à 1,30 m do solo, sendo confeccionados com dimensões de 5,0 $\times 5,0 \times 15,0 \mathrm{~cm}$ para a avaliação de secagem em estufa, com as dimensões de $1,5 \times 1,5 \times 2,0 \mathrm{~cm}$ para as características anatômicas. O $S$. parahyba possui os maiores valores de diâmetro das fibras $(35,1 \mu \mathrm{m})$ e do diâmetro do lume $(27,6 \mu \mathrm{m})$, já $P$. dubium apresentou os maiores valores de espessura da parede celular $(6,8 \mu \mathrm{m})$. O teor de umidade de equilíbrio médio foi de $10,98 \%$ aos 40 dias de secagem. A anatomia da madeira influenciou na secagem das quatro espécies, se correlacionando ao teor de umidade durante todos os períodos. Os parâmetros anatômicos que mais influenciaram na secagem foram o diâmetro da fibra $(0,77)$, diâmetro do lume da fibra $(0,76)$ e espessura da parede celular da fibra $(0,73)$, quanto maiores os valores, maior a intensidade de secagem.
\end{abstract}

Palavras-Chave: teor de umidade, fibras, correlação.

\begin{abstract}
Drying is an important process in the generation of wood products, as it increases the quality of the final products; however, it is influenced by various anatomical characteristics. The aim of this study was to evaluate the influence of anatomy on the drying of wood of Parapiptadenia rigida (Benth.) Brenan, Peltophorum dubium (Spreng.) Taub., Eucalyptus grandis W. Hill $\times$ Eucalyptus urophylla S.T. Blake (hybrid), and Schizolobium parahyba (Vell.) Blake trees from an agroforestry system. Three trees aged 9 years were sampled for each species. The trees were removed from the study region when their diameter at breast height (DBH) was $1.30 \mathrm{~m}$ from the ground. Blocks were made with dimensions of $5.0 \times 5.0 \times 15.0 \mathrm{~cm}$ for the evaluation of oven drying and $1.5 \times 1.5 \times 2.0 \mathrm{~cm}$ for anatomical features. $S$. parahyba has the highest value of fiber diameter $(35.1 \mu \mathrm{m})$ and lumen diameter $(27.6 \mu \mathrm{m})$, whereas $P$. dubium had the highest value of cell wall thickness $(6.8$ $\mu \mathrm{m})$. The average equilibrium moisture content was $10.98 \%$ after 40 days of drying. The anatomy of the wood influenced the drying of the four species intensity, which was related to humidity during all periods. The anatomical parameters that most influenced drying were fiber diameter (Pearson correlation coefficient: 0.77), lumen diameter (0.76), and fiber cell wall thickness (0.73); the higher the values, the greater was the drying intensity.

Keywords: moisture content, fibers, correlation.
\end{abstract}

\section{INTRODUCTION}

Agroforestry systems (SAFs) involve the introduction of forest components for interactions with agricultural components. SAFs have been developed with specific characteristics regarding the species used, which are adapted to the location, with productive potential and interact with each other, the temporal arrangement that responds to the plan over time, and spatial arrangement of the components with spacing between plants according to the objectives and functionality of the system (SCHWERZ et al., 2018). Globally, interest in the implementation of SAFs has grown, and efforts for its diffusion in Brazil are considerable.

SAFs are promising alternatives to establishing consortiums of both native and exotic tree species for wood production while simultaneously conserving natural resources. Although only a few studies have compared 
the productivity or quality of wood derived from SAFs and monocultures of trees, such systems are responsible for yielding economic benefits by diversifying production in small rural properties and generating income. In addition, they enhance ecological benefits such as the reduction of soil degradation (CARON et al., 2018), thus protecting the surrounding environment.

In this study, during the implementation of SAFs, four native and exotic forest species were chosen: Parapiptadenia rigida (Benth.) Brenan, Peltophorum dubium (Spreng.) Taub., Schizolobium parahyba (Vell.) Blake and Eucalyptus grandis W. Hill $\times$ Eucalyptus urophylla S.T. Blake (hybrid); these species are of commercial interest and are grown in the study region by small farmers. These species have different growth and productivity characteristics, which are still being evaluated.

To expand the application of wood from SAFs, it is necessary to identify the characteristics and technological behavior of different types of wood (MOTTA et al., 2014). For this purpose, methods, such as drying, have been developed to improve the physical and mechanical characteristics of the materials (FREITAS et al., 2016).

Drying is an important process in the generation of solid wood products because of the known benefits added to the materials by this technique, such as increasing dimensional stability, decreasing hygroscopicity (MODES et al., 2017), reducing the risk of attack by xylophagous organisms, and enhancing the ease of workability of the material (BATISTA et al., 2013). Thus, adequate drying contributes to increasing the quality of the final product, thereby meeting the standards required by the industry.

The study of wood anatomy contributes to the characterization and differentiation of woody plant species, in addition to providing subsidies for studies on their properties, growth, behavior, quality and drying of wood. Anatomical elements such as vessels, fibers, and radial and axial parenchyma cells make wood a porous material, characterizing it as a complex structure for the passage of liquid and gaseous fluids. Water moves mainly through vessels and pairs of scores in the cells (MONTEIRO et al., 2017).

Wood is a forest resource of great importance because it is a highly hygroscopic, heterogeneous, and anisotropic biological material. Variations in its anatomical parameters alter the dimensions and frequency of the cells, directly affecting the physical and mechanical properties. Hygroscopicity gives the material the ability to exchange moisture with the medium in which it is placed; hence, it will lose moisture in dry environments and gain moisture in humid environments. Heterogeneity is due to a set of diverse components that perform specific functions in various tissues that form complex individuals, each with their own properties and characteristics. Anisotropy, however, is a characteristic of wood, in which a certain physical property can vary its dimensions in the tangential, radial, and longitudinal directions. Each direction can react in different ways to both applied loads and drying, directly exerting an effect on the end use of the product (BRAZ et al., 2015).

Consequently, the use of species for agroforestry must consider wood quality characteristics, in addition to their other attributes, to meet production requirements. Therefore, multiple-purpose species should be selected for use in SAFs to facilitate their choice in different situations.

The study had the following hypotheses: the anatomy of the wood correlates with the drying of the wood, and the anatomical elements that most correlate are those that perform the transport function. The aim of the present study was to evaluate the influence of anatomy on the drying of wood from four species of an SAF.

\section{MATERIALS AND METHODS}

\section{Experiment location}

The wood of the four tree species - namely, Parapiptadenia rigida (Benth.) Brenan (angico-vermelho), Peltophorum dubium (Spreng.) Taub. (canafístula), Eucalyptus grandis W. Hill $\times$ Eucalyptus urophylla S.T. Blake (hybrid) (eucalipto), and Schizolobium parahyba (Vell.) Blake (guapuruvú) - was obtained from an SAF located at the Federal University of Santa Maria, Frederico Westphalen campus (UFSM/FW), Rio Grande do Sul (27 $22^{\prime}$ $\mathrm{S} ; 53^{\circ} 25^{\prime} \mathrm{W}$ ) at an altitude of $480 \mathrm{~m}$. According to the Köppen classification, the predominant climate in the region is characterized as sub-temperate sub-humid, with an average temperature of $18.8^{\circ} \mathrm{C}$ annually and $13.3{ }^{\circ} \mathrm{C}$ during the coldest month.

For each species, three trees aged approximately 9 years were sampled. They were planted with a spacing of $12.0 \mathrm{~m} \times 3.0 \mathrm{~m}$. The trees were removed from the region when their diameter at breast height $(\mathrm{DBH})$ was 1.30 $\mathrm{m}$ from the ground. Table 1 shows the average values of total height, DBH, and basic density $\left(\rho_{\mathrm{b}}\right)$ for the wood of the evaluated four species. 
Table 1. Average values of total height, diameter at breast height (DBH) and basic density $\left(\rho_{b}\right)$ of wood of the four forest species evaluated.

Tabela 1. Valores médios de altura total, diâmetro à altura do peito $(\mathrm{DBH})$ e massa específica básica $\left(\rho_{\mathrm{b}}\right)$ da madeira das quatro espécies florestais avaliadas.

\begin{tabular}{cccc}
\hline Species & Height $(\mathrm{m})$ & DBH $(\mathrm{cm})$ & $\rho_{\mathrm{b}}\left(\mathrm{g} . \mathrm{cm}^{-3}\right)$ \\
\hline P. rigida & 13.77 & 18.49 & 0.750 \\
P. dubium & 13.88 & 16.88 & 0.548 \\
E. grandis $\times$ E. urophylla & 22.81 & 38.09 & 0.564 \\
S. parahyba & 17.97 & 27.23 & 0.322 \\
\hline
\end{tabular}

\section{Anatomy of Wood}

For anatomical analysis, blocks with dimensions of $1.5 \times 1.5 \times 2.0 \mathrm{~cm}$ were prepared and oriented to show the transverse, longitudinal radial, and tangential anatomical planes, with 9 samples per species, totaling 36 samples.

Microtomy was performed according to the technical standard IAWA (1989). For histological evaluation, the specimens were softened following the traditional technique. Briefly, the specimens were boiled in water, tested, and cut (with a thickness of $18 \mu \mathrm{m}$ ) on a sliding microtome. Once the materials were sliced, they were double stained with Astra Blue and safranin and then dehydrated in an alcoholic series $(30 \%, 50 \%, 70 \%, 90 \%$, and 100\%). Then, permanent slides were assembled using Entellan glue.

According to the recommendations of Franklin (1945), maceration of the slivers was carried out; they were boiled for $45 \mathrm{~min}$ in an acid solution. To stain the woody cell paste, safranin was applied, followed by dehydration in an alcohol series (50\%). The same medium previously mentioned for the assembly of permanent slides was used.

For each anatomical parameter, 75 measurements were performed according to the technical standard COPANT (1973). Using the histological sections, the diameter and frequency of the vessels and the height and width of the rays were evaluated. Using the macerated material, the length, width, and diameter of the lumen of the fibers were measured. To calculate the cell wall thickness of the fibers, the following equation was used:

$$
\mathrm{Cwt}=(\mathrm{Fw}-\mathrm{Lw}) / 2
$$

where Cwt is the cell wall thickness $(\mu \mathrm{m}), \mathrm{Fw}$ is the fiber width $(\mu \mathrm{m})$, and Lw is the lumen width $(\mu \mathrm{m})$.

To calculate the cell wall fraction, the following equation was used:

$$
\mathrm{Cwf}=(2 \times \mathrm{Cwt}) / \mathrm{Fw} \times 100
$$

where Cwf is the cell wall fraction $(\%)$, Cwt is the cell wall thickness $(\mu \mathrm{m})$, and Fw is the fiber width $(\mu \mathrm{m})$.

\section{Wood drying}

For the evaluation of wood drying, after cutting the trees, 25 samples were made for each study material, from the heartwood and sapwood region, with dimensions of $5 \times 5 \times 15 \mathrm{~cm}$, for the radial, tangential, and longitudinal orientations, respectively.

To determine the green weight of the samples, a precision electronic scale was used to weigh the materials obtained from the field; the initial moisture content was determined. The samples were then placed in a drying oven controlled for temperature $\left( \pm 22^{\circ} \mathrm{C}\right)$ and humidity $( \pm 55 \%)$ with the aid of a digital thermohygrometer.

The moisture loss of the study materials was monitored for 40 days. The specimens were weighed twice a day in the first week and once a day thereafter. The moisture content of the dry base was calculated using the following equation:

$$
\text { TUbs }=(\mathrm{Pu}-\mathrm{Ps}) / \mathrm{Ps} \times 100
$$

where TUbs is the moisture content of the dry base $(\%), \mathrm{Pu}$ is the wet weight $(\mathrm{g})$, and Ps is the dry weight (g).

The equilibrium moisture content was determined according to the methodology developed by Simpson 
After the 40-day drying period (May 2017-June 2017), the specimens-stabilized at equilibrium moisture-were placed in an oven with forced air circulation at $103{ }^{\circ} \mathrm{C}$ for drying at $0 \%$. Subsequently, the materials were removed and weighed on the precision electronic scale to determine the dry mass.

\section{Experimental design and data analyses}

For the assembly and statistical analyses of the data, a completely randomized design was used. The data were subjected to statistical analyses, including the analysis of variance, F test, Shapiro-Wilk test for normality, Bartlett's test for heteroscedasticity, Pearson's correlation test, and Tukey's means test at 5\% probability of error. The "Statistical Analysis System" (SAS 2003) software was used for the statistical analyses.

\section{RESULTS}

Data analyses showed that the four forest species exhibited differences in all the evaluated anatomical parameters. $S$. parahyba wood had the highest values for fiber diameter $(35.1 \mu \mathrm{m})$, lumen diameter $(27.6 \mu \mathrm{m})$ and vessel diameter $(187.1 \mu \mathrm{m})$. It also had the largest ray dimensions — both height $(256.4 \mu \mathrm{m})$ and width $(38.2 \mu \mathrm{m})$. In contrast, it had the lowest values for vessel frequency $\left(1.8\right.$ pores $\left./ \mathrm{mm}^{2}\right)$ and cell wall fraction $(21.6 \%)($ Table 2$)$.

Table 2. Anatomical analysis of forest species samples in na agroforestry system.

Tabela 2. Análise anatômica das amostras de espécies florestais em um sistema agroflorestal.

\begin{tabular}{|c|c|c|c|c|c|}
\hline Species & $\begin{array}{l}\text { F.L. } \\
(\mu \mathrm{m})\end{array}$ & $\begin{array}{l}\text { F.D. } \\
(\mu \mathrm{m})\end{array}$ & $\begin{array}{l}\text { L.D. } \\
(\mu \mathrm{m})\end{array}$ & $\begin{array}{l}\text { C.W.T. } \\
(\mu \mathrm{m})\end{array}$ & $\begin{array}{c}\text { C.W.F. } \\
(\%)\end{array}$ \\
\hline P. rigida & $872.6^{116.2} \mathrm{a}$ & $13.4^{2.8} \mathrm{c}$ & $5.7^{1.6} \mathrm{~b}$ & $3.9^{0.8} \mathrm{~b}$ & $57.8^{6.7} \mathrm{ab}$ \\
\hline P. dubium & $690.2^{134.9} \mathrm{~b}$ & $21.8^{5.9} \mathrm{~b}$ & $8.1^{4.3} \mathrm{~b}$ & $6.8^{2.0} \mathrm{a}$ & $64.0^{13.8} \mathrm{a}$ \\
\hline $\begin{array}{l}\text { E. grandis } \times \\
\text { E. urophylla }\end{array}$ & $850.1^{160.7} \mathrm{a}$ & $12.9^{2.7} \mathrm{c}$ & $5.9^{2.0} \mathrm{~b}$ & $3.5^{0.9} \mathrm{~b}$ & $55.2^{9.5} \mathrm{~b}$ \\
\hline S. parahyba & $882.1^{178.4} \mathrm{a}$ & $35.1^{6.1} \mathrm{a}$ & $27.6^{5.9} \mathrm{a}$ & $3.7^{1.1} \mathrm{~b}$ & $21.6^{6.5} \mathrm{c}$ \\
\hline Species & $\begin{array}{l}\text { V.D. } \\
(\mu \mathrm{m})\end{array}$ & $\begin{array}{c}\text { V.F. } \\
\text { (pores } / \mathrm{mm}^{2} \text { ) }\end{array}$ & $\begin{array}{l}\text { R.H. } \\
(\mu \mathrm{m})\end{array}$ & \multicolumn{2}{|c|}{$\begin{array}{l}\text { R.W. } \\
(\mu \mathrm{m})\end{array}$} \\
\hline$P$. rigida & $89.1^{13.5} \mathrm{c}$ & $6.6^{1.7} \mathrm{~b}$ & $132.9^{31.4} \mathrm{c}$ & \multicolumn{2}{|c|}{$19.3^{3.2} \mathrm{c}$} \\
\hline P. dubium & $123.9^{21.1} \mathrm{~b}$ & $4.0^{1.3} \mathrm{c}$ & $189.5^{45.9} \mathrm{~b}$ & \multicolumn{2}{|c|}{$25.1^{7.0} \mathrm{~b}$} \\
\hline $\begin{array}{l}\text { E. grandis } \times \\
\text { E. urophylla }\end{array}$ & $86.6^{23.5} \mathrm{c}$ & $14.8^{2.2} \mathrm{a}$ & $168.9^{60.8} \mathrm{~b}$ & \multicolumn{2}{|c|}{$13.5^{3.5} \mathrm{~d}$} \\
\hline S. parahyba & $187.1^{43.4} \mathrm{a}$ & $1.8^{0.9} \mathrm{~d}$ & $256.4^{47.3} \mathrm{a}$ & \multicolumn{2}{|c|}{$38.2^{5.8} \mathrm{a}$} \\
\hline
\end{tabular}

Where: F.L. = Fiber Lenght; F.D. = Fiber Diameter; L.D. = Lume Diameter; C.W.T. = Cell Wall Thickness; C.W.F. = Cell Wall Fraction; V.D. = Vessel Diameter; V.F. = Vessel Frequency; R.H. = Ray Height and R.W. = Ray Width. Where: Means followed by the same letter in the column compare species and do not differ, according to the Tukey test at 5\%. Values in superscript represent the standard deviation.

P. dubium presented the highest values for fiber wall thickness $(6.8 \mu \mathrm{m})$ and cell wall fraction $(64.0 \%)$, which was not different from the fraction of $P$. rigida. However, the lowest values for fiber length $(690.2 \mu \mathrm{m})$ and vessel frequency $\left(4.0\right.$ pores $\left./ \mathrm{mm}^{2}\right)$ were observed for this species. In contrast, E. grandis $\times$ E. urophylla showed the highest vessel frequency $\left(14.8\right.$ pores $\left./ \mathrm{mm}^{2}\right)$ and the smallest ray width $(13.5 \mu \mathrm{m})$ compared with the other species. It had significant similarities with $P$. rigida in terms of the anatomical characteristics of the fibers and the diameter of the vessels (Table 2).

The initial moisture content ranged from $66.67 \%$ to $190.90 \%$ for $P$. rigida and S. parahyba, respectively; however, these species had different drying rates during the evaluation period. The species $S$. parahyba, E. grandis $\times$ E. urophylla, and $P$. rigida achieved equilibrium moisture content of $9.65,11.19$ and $12.12 \%$, respectively (Figure 1) between days 35 and 40 of drying. The average equilibrium moisture content of these materials was $10.98 \%$. P. dubium did not achieve equilibrium moisture content even after 40 days of drying. 


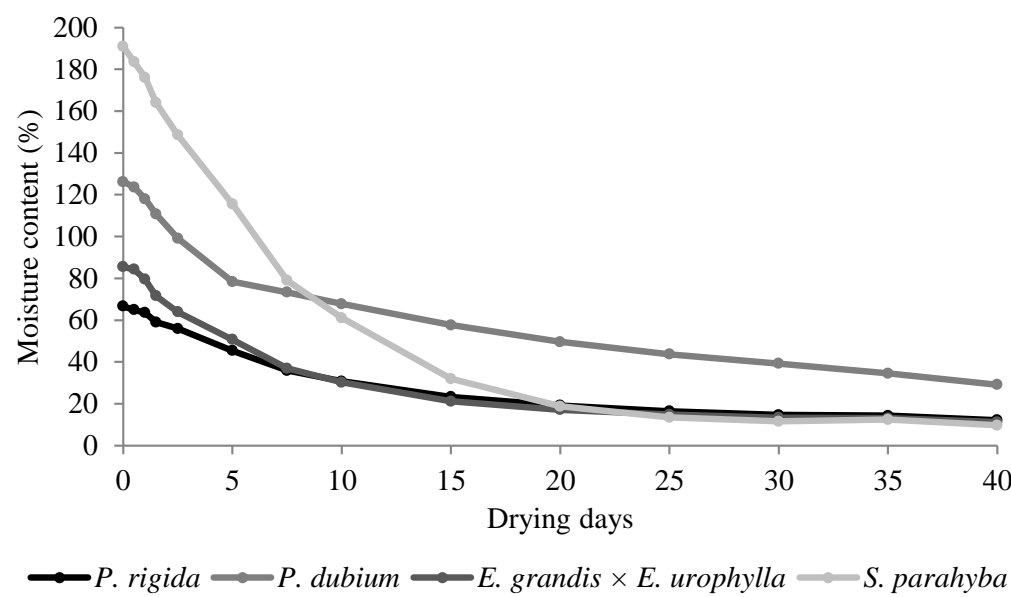

Figure 1. Moisture content of wood from forest species up to 40 days of drying.

Figura 1. Teor de umidade da madeira de espécies florestais até os 40 dias de secagem.

The highest rate of total drying was observed for S. parahyba (4.53\%/day), followed by P. dubium (2.42 $\% /$ day $)$, E. grandis $\times$ E. urophylla $(1.85 \% /$ day $)$, and $P$. rigida $(1.36 \% /$ day $)$.

The highest Pearson's correlation coefficients between anatomy and drying were observed for fiber diameter (0.77), lumen diameter (0.76), cell wall thickness (0.73), and vessel diameter (0.64), which were directly proportional to the drying times. The fiber length showed a significant inverse correlation after 7.5 days of drying (Table 3).

Table 3. Pearson's correlation coefficient between anatomy and wood moisture content of four forest species.

Tabela 3. Coeficiente de correlação de Pearson entre anatomia e secagem da madeira de quatros espécies florestais.

\begin{tabular}{|c|c|c|c|c|c|c|c|}
\hline \multirow{2}{*}{$\begin{array}{l}\text { Anatomical } \\
\text { parameter }\end{array}$} & \multicolumn{7}{|c|}{ Drying days } \\
\hline & 0 & 0.5 & 1 & 1.5 & 2.5 & 5 & 7.5 \\
\hline F.L. & $-0.02^{\mathrm{ns}}$ & $-0.03^{\mathrm{ns}}$ & $-0.03^{\mathrm{ns}}$ & $-0.09^{\mathrm{ns}}$ & $-0.07^{\mathrm{ns}}$ & $-0.12^{\mathrm{ns}}$ & $-0.21 *$ \\
\hline F.D. & $0.77 *$ & $0.77^{*}$ & $0.76^{*}$ & $0.72 *$ & $0.76^{*}$ & $0.74 *$ & $0.69^{*}$ \\
\hline L.D. & $0.76^{*}$ & $0.75 *$ & $0.74 *$ & $0.71 *$ & $0.73 *$ & $0.68 *$ & $0.57 *$ \\
\hline C.W.T. & $0.07^{\mathrm{ns}}$ & $0.08^{\mathrm{ns}}$ & $0.09^{\mathrm{ns}}$ & $0.06^{\mathrm{ns}}$ & $0.12^{\mathrm{ns}}$ & $0.19^{\mathrm{ns}}$ & $0.36^{*}$ \\
\hline C.W.F. & $-0.59 *$ & $-0.58 *$ & $-0.57 *$ & $-0.54 *$ & $-0.55^{*}$ & $-0.49 *$ & $-0.39 *$ \\
\hline V.D. & $0.64 *$ & $0.63 *$ & $0.63 *$ & $0.57 *$ & $0.63^{*}$ & $0.61 *$ & $0.56^{*}$ \\
\hline V.F. & $-0.53^{*}$ & $-0.52 *$ & $-0.53 *$ & $-0.49^{*}$ & $-0.56^{*}$ & $-0.60 *$ & $-0.62 *$ \\
\hline R.H. & $0.61 *$ & $0.60 *$ & $0.60 *$ & $0.54^{*}$ & $0.59 *$ & $0.59 *$ & $0.52 *$ \\
\hline R.W. & $0.66^{*}$ & $0.64 *$ & $0.65^{*}$ & $0.62 *$ & $0.66^{*}$ & $0.63^{*}$ & $0.60 *$ \\
\hline \multirow{2}{*}{$\begin{array}{l}\text { Anatomical } \\
\text { parameter }\end{array}$} & \multicolumn{7}{|c|}{ Drying days } \\
\hline & 10 & 15 & 20 & 25 & 30 & 35 & 40 \\
\hline F.L. & $-0.30 *$ & $-0.41 *$ & $-0.43^{*}$ & $-0.46^{*}$ & $-0.46^{*}$ & $-0.46^{*}$ & $-0.46^{*}$ \\
\hline F.D. & $0.58^{*}$ & $0.29 *$ & $0.09^{\mathrm{ns}}$ & $0.01^{\mathrm{ns}}$ & $-0.01^{\mathrm{ns}}$ & $0.02^{\mathrm{ns}}$ & $-0.01^{\mathrm{ns}}$ \\
\hline L.D. & $0.41 *$ & $0.04^{\mathrm{ns}}$ & $-0.17^{\mathrm{ns}}$ & $-0.26 *$ & $-0.28 *$ & $-0.25 *$ & $-0.29 *$ \\
\hline C.W.T. & $0.50^{*}$ & $0.69 *$ & $0.72 *$ & $0.73^{*}$ & $0.72 *$ & $0.72 *$ & $0.72 *$ \\
\hline C.W.F. & $-0.14^{\mathrm{ns}}$ & $0.23 *$ & $0.42 *$ & $0.47^{*}$ & $0.49 *$ & $0.47 *$ & $0.49 *$ \\
\hline V.D. & $0.46^{*}$ & $0.21 *$ & $0.05^{\mathrm{ns}}$ & $-0.02^{\mathrm{ns}}$ & $-0.03^{\mathrm{ns}}$ & $-0.01^{\mathrm{ns}}$ & $-0.03^{\mathrm{ns}}$ \\
\hline V.F. & $-0.60^{*}$ & $-0.45^{*}$ & $-0.33^{*}$ & $-0.27 *$ & $-0.26^{*}$ & $-0.29 *$ & $-0.26^{*}$ \\
\hline R.H. & $0.44^{*}$ & $0.19^{\mathrm{ns}}$ & $0.05^{\mathrm{ns}}$ & $-0.01^{\mathrm{ns}}$ & $-0.02^{\mathrm{ns}}$ & $0.01^{\mathrm{ns}}$ & $-0.02^{\mathrm{ns}}$ \\
\hline R.W. & $0.50 *$ & $0.24 *$ & $0.07^{\mathrm{ns}}$ & $0.01^{\mathrm{ns}}$ & $0.01^{\mathrm{ns}}$ & $0.03^{\mathrm{ns}}$ & $0.01^{\mathrm{ns}}$ \\
\hline
\end{tabular}

Where: F.L. = Fiber Length; F.D. = Fiber Diameter; L.D. = Lume Diameter; C.W.T. = Cell Wall Thickness; C.W.F. $=$ Cell Wall Fraction; V.D. = Vessel Diameter; V.F. = Vessel Frequency; R.H. = Ray Height and R.W. = Ray Width. ${ }^{*}=$ Significant Pearson correlation; ns $=$ Pearson's correlation not significant. 
The frequency of vessels was inversely proportional to the number of days required to dry. This characteristic was also observed for cell wall fraction, which correlated negatively until 7.5 days and positively after 15 days. Conversely, the height and width of the rays correlated positively up to 10 and 15 days, respectively.

\section{DISCUSSION}

Based on the results, the species showed differences between each other in all evaluated anatomical parameters. This characteristic is important, because a heterogeneous collection of materials is warranted to assess the influence of anatomical parameters on the drying process more accurately (ZANUNCIO et al., 2016). This difference in anatomy influences drying intensity, and it deepens our understanding of this relationship for drying each species separately.

The highest values for fiber length, diameter, lumen diameter, vessel diameter, and ray height and width were observed for $S$. parahyba when compared with those of the other species (Table 2). The variation in these anatomical variables among the selected species is associated with differences in their genetic materials and environmental conditions (PILLAI et al., 2013). Among the studied species, S. parahyba was characterized as the species with the highest porosity, in relation to the diameter of the vessels. This result corroborates that reported by Nisgoski et al. (2012), who observed an average value of $202.20 \mu \mathrm{m}$ for the diameter of the vessels and a frequency of 2.02 pores $/ \mathrm{mm}^{2}$ for this species. This greater porosity that the species presents, directly influences the lower basic density of the wood.

The highest value of vessel frequency was found for E. grandis $\times$ E. urophylla (Table 2), which was in line with the average value (14.91 pores $/ \mathrm{mm}^{2}$ ) obtained for this species by Lima et al. (2019). Hence, the higher the frequency of the vessels, the smaller is the lumen diameter (Table 2); this trend directly influences the drying of the wood in an inversely proportional manner (Figure 1).

The species $P$. rigida and $P$. dubium showed the highest values for the cell wall fraction. According to Sette Junior et al. (2012), an increase in the cell wall fraction increases the basic density of the wood, consequently improving its mechanical properties and making the wood highly resistant.

The removal of water or loss of moisture from the wood was the greatest during the first days of drying for all species (Figure 1). This corroborates the results reported by Zanuncio et al. (2013) for E. urophylla and by Ananias et al. (2013) for Pinus radiata. According to Kollmann and Côté (1968), during the initial period, the loss of free water occurs because the weak capillary connection between the wood and the water molecules is easily broken. This behavior was observed during the first drying days (Table 3), during which the highest correlation values were reported for anatomical parameters associated the elements that perform the conduction and transportation of liquids, such as the diameter of the lumen, diameter of the vessel, and height and width of the rays.

S. parahyba had the highest initial moisture content, which was the species that first reached equilibrium moisture content (TUe). The maximum moisture content was associated with dimensions of empty wood spaces (vessels and lumens) such as lumen diameter $(27.6 \mu \mathrm{m})$, vessel diameter $(187.1 \mu \mathrm{m})$ and ray width $(38.2 \mu \mathrm{m})$. These spaces facilitate water flow and promote drying. Likewise, Zanuncio et al. (2013) reported that for $E$. urophylla, materials with higher initial humidity had a higher drying rate.

The average TUe found for the species under study was similar to that found by Fioresi et al. (2014), who observed an average value of $14.9 \%$ at 40 days of drying. The difficulty in removing moisture from wood can vary between different species and based on their anatomical properties (ALAN et al., 2010). This explains why the species reached their TUe at different time periods (Figure 1). P. rigida, S. parahyba, and E. grandis $\times$ E. urophylla reached TUes between 35 and 40 days (Figure 1). This result agrees with that reported by Eleoterio et al. (2014), who stated that it is difficult to dry E. grandis $\times$ E. urophylla when compared with other species because it dries slowly and has a high propensity to develop defects.

P. dubium did not reach TUe until 40 days, indicating slower drying than other species. This may have been influenced by the high thickness and fraction of the cell wall. The higher the cell wall values, the more difficult it is to remove the permeated water, which occurs close to $30 \%$ of the moisture content of the wood, also known as the saturation point of the fibers.

It was proven that the fiber diameter and lumen diameter directly influenced the drying of the wood (Table 3). This occurred most notably in $S$. parahyba, where high correlations were observed. In the initial periods of drying, water loss was rapid from the wood. For $P$. rigida and $E$. grandis $\times E$. urophylla, which presented low values of these variables, drying was slow.

The relationship of the cell wall thickness and lumen diameter with drying was greater than that of fiber length with drying because water passes through the fibers in a transverse direction during the drying process (ENGELUND et al., 2013; ZANUNCIO et al., 2016). According to Kollmann and Côté (1968), the lumen diameter and cell wall thickness influence the drying of wood in different ways; the diameter greatly influences drying at 
the beginning, whereas the thickness influences at the end of the drying period (Table 3). However, water transmission during wood moisture loss occurs mainly by diffusion through the fibers.

Pearson's correlation coefficients for cell wall thickness and moisture content with drying were significantly positive from 7.5 days to 40 days (Table 3 ). These correlations may be related to the pattern of water loss from the wood, which initially occurs in a free form from the cell lumens. At the end of the drying period, the water within the cell walls was removed (Table 3). Therefore, materials with higher cell wall fraction values have a lower void volume and thus hold less moisture when saturated. The presence of a large volume of fibers prevents the passage of water and reduces the speed of drying (KOLLMANN and CÔTÉ, 1968).

The characteristics of the vessels were strong indicators of wood drying. The larger the diameter of the vessels, the greater was the speed of water removal from the wood. In contrast, the higher the frequency of vessels per $\mathrm{mm}^{2}$, the lower was the drying rate. Hence, species that have larger lumen diameters dry faster, as the removal of water from the wood is promoted. This finding explains why S. parahyba wood dried faster than E. grandis $\times$ E. urophylla wood.

Furthermore, it was observed that the lower the frequency of vessels per $\mathrm{mm}^{2}$, the larger were the diameters of the vessels and, consequently, those of their lumens (Table 2). This pattern was observed for the species E. grandis $\times$ E. urophylla and $S$. parahyba, which showed very different values for the mentioned variables; hence, drying intensity for these species was different. Therefore, the elements of the vessels may have a substantial influence on drying, especially during the initial drying periods, as these elements facilitate the transport of water in the wood. This explains the relationship of the diameter and frequency of vessels with drying and corroborates the results reported by Zanuncio et al. (2016), who used the same hybrid E. grandis $\times$ E. urophylla. They observed that the maximum moisture content is associated with the dimensions of the empty spaces within the wood (vessels and cell lumens) and that these spaces facilitate the drainage of water and promote drying. They also reported that the diameter and frequency of the vessels have a considerable influence on drying, as they facilitate the transport of water inside the wood.

From Pearson's correlation analysis, it was observed that the anatomy of the wood of the studied species influenced drying and must be considered in wood drying programs. The highest correlation coefficients were observed for fiber diameter (0.77), lumen diameter (0.76), cell wall thickness (0.73), and vessel diameter (0.64), which were directly proportional to the drying time (Table 3). This study is relevant to improve the precision of analysis of the anatomical variables involved in the drying process.

\section{CONCLUSIONS}

- $\quad$ From the evaluation of the anatomy and drying of the wood of P. rigida, P. dubium, E. grandis $\times$ E. urophylla, and $S$. parahyba from an SAF, it can be concluded that:

- Moisture loss is the greatest during the initial drying stages.

- Anatomy of the wood influences the drying of the four species intensity, which is further related to humidity during all periods.

- The anatomical parameters that most influence drying are fiber diameter, lumen diameter, and cell wall thickness. The higher the values, the greater is the drying intensity.

\section{REFERENCES}

ALAN, V. M.; MODES, K. S.; BELTRAME, R.; MORAIS, W. C.; SOUZA, J. T.; MACHADO, W. G.; SANTINI, E. J.; HASELEIN, C. R. Resistência da madeira de canafístula (Peltophorum dubium (Spreng.) Taub.) ao psf e a umidade de equilíbrio. Ciência da Madeira, Pelotas, v. 1, n. 1, p. 11-24, 2010.

ANANIAS, R. A.; MENA, M.; ELUSTONDO, D. M.; DIAZ-VAZ, J. E.; VALENZUELA, L.; SALINAS, C. Testing new in-kiln meter for monitoring lumber moisture content during drying. Drying Technology: An International Journal, Estados Unidos, v. 31, n. 3, p. 277-281, 2013.

BATISTA, D. C.; KLITZKE, R. J.; ROCHA, M. P. Qualidade da secagem convencional conjunta da madeira de clones de três espécies de Eucalyptus ssp. Ciência Florestal, Santa Maria, v. 3, n. 25, p. 711-719, 2013.

BRAZ, R. L.; DUARTE, A. P. C.; OLIVEIRA, J. T. S.; MOTTA, J. P.; ROSADO, A. M.; Curva característica de secagem da madeira de Tectona grandis e Acacia mangium ao ar livre. Floresta e Ambiente, Rio de Janeiro, v. 22, n. 1, p. 117-123, 2015.

CARON, B. O.; ELLI, E. F.; BEHLING, A.; ELOY, E.; SCHMIDT, D.; STOLZLE, J. Growth of tree species and sugarcane production in agroforestry systems. Anais da Academia Brasileira de Ciências, Rio de Janeiro, v. 90 , n. 2, p. 2425-2436, 2018. 
COMISSÃO PANAMERICANA DE NORMAS TÉCNICAS. COPANT 30: descrição macroscópica, microscópica e geral da madeira - esquema I de recomendação. Colômbia, 1973.

ELEOTÉRIO, J. R.; HORNBURG, K. F.; REICHERT. D.; BAGATTOLI. T. R.; MENEGHELLI, I. Efeito da espécie e da condição de secagem na formação de defeitos na madeira serrada de eucalipto. Scientia Forestalis, Piracicaba, v. 42, n. 101, p. 41-47, 2014.

ENGELUND, E. T.; THYGESEN, L. G.; SVENSSON, S.; HILL, C. A. S. A critical discussion of the physics of wood-water interactions. Wood Science and Technology, Munique, v. 47, n. 1, p. 141-161, 2013.

FIORESI, T.; PIROCA, S.; COSTA, H. W. D.; TREVISAN, R.; FORTES, F. O.; GATTO, D. A. Umidade de equilíbrio da madeira na região norte do Rio Grande do Sul em diferentes estações do ano. Ciência da Madeira, Pelotas, v. 5, n. 1, p. 34-41, 2014.

FRANKLIN, G. L. Preparation of thin sections of synthetic resins and wood: resin composites, and a new macerating method for wood. Nature, New York, v. 155, p. 51, 1945.

FREITAS, A. S.; GONÇALEZ, J. C.; MENEZZI, C. H. Tratamento termomecânico e seus efeitos nas propriedades da Simarouba amara (Aubl.). Floresta e Ambiente, Rio de Janeiro, v. 23, n. 4, p. 565-572, 2016.

INTERNATIONAL ASSOCIATION OF WOOD ANATOMISTS. IAWA 1989: list of microscopic features for hardwood identification. Bulletin, Leiden, 1989.

KOLlMANN, F. F. P.; CÔTÉ, W. A. Principles of Wood Science and Technology: solid wood. Berlin: Springer, 1 ed. 1968.55 p.

LIMA, P. A. F.; DEMARCHI, J.; SILVA, M. F.; MORAES, M. D. A.; CALDAS, D. J.; SETTE JR, C. R. Qualidade da madeira de eucalipto para aplicação como mourão tratado. Revista de Ciências Agrárias, Recife, v. 42, n. 2, p. 509-519, 2019.

MODES, K. S.; SANTINI, E. J.; VIVIAN, M. A.; HASELEIN, C. R. Efeito da termorretificação nas propriedades mecânicas das madeiras de Pinus taeda e Eucalyptus grandis. Ciência Florestal, Santa Maria, v. 27, n. 1, p. 291302, 2017.

MONTEIRO, T. C.; LIMA, J. T.; HEIN, P. R. G.; SILVA, J. R. M.; TRUGILHO, P. F.; ANDRADE, E. B. Efeito dos elementos anatômicos da madeira na secagem das toras de Eucalyptus e Corymbia. Scientia Forestalis, Piracicaba, v. 45, n. 115, p. 493-505, 2017.

MOTTA, J.P.; OLIVEIRA, J. T. S.; BRAZ, R. L.; DUARTE, A. P. C.; ALVES, R. C. Caracterização da madeira de quatro espécies florestais. Ciência Rural, Santa Maria, v. 44, n. 12, p. 2186-2192, 2014.

NISGOSKI, S.; MUÑIZ, G. I. B.; TRIANOSKI, R.; MATOS, J. L. M.; VENSON, I. Características anatômicas da madeira e índices de resistência do papel de Schizolobium parahyba (Vell.) Blake proveniente de plantio experimental. Scientia Forestalis, Piracicaba, v. 40, n. 94, p. 203-211, 2012.

PILlAI, P. H. C.; PANDALAI, R. C.; DHAMODARAN, T. K.; SANKARAN, K. V. Effect of silvicultural practices on fibre properties of Eucalyptus wood from short-rotation plantations. New Forests, Sydney, v. 44, n. 4, p. 521-532, 2013.

SAS. Statistical Analysis System. Getting Started with the SAS Learning Edition. Care, North Carolina: SAS Institute Inc, 2003. 200 p.

SCHWERZ, F.; MEDEIROS, S. L. P.; ELLI, E. F.; ELOY, E.; SGARBOSSA, J.; CARON, B. O. Plant growth, radiation use efficiency and yield of sugarcane cultivated in agroforestry systems: An alternative for threatened ecosystems. Anais da Academia Brasileira de Ciências, Rio de Janeiro, v. 90, n. 4, p. 3265-3283, 2018.

SETTE JUNIOR, C. R.; OLIVEIRA, I. R.; TOMAZELLO FILHO, M.; YAMAJI, F. M.; LACLAU, J. P. Efeito da idade e posição de amostragem na densidade e características anatômicas da madeira de Eucalyptus grandis. Revista Árvore, Viçosa, v. 36, n. 6, p. 1183-1190, 2012.

SIMPSON, W. T. Equilibrium moisture content prediction for wood. Forest Products Journal, LaGrange, v. 21, n. 5, p. 48-49, 1971.

ZANUNCIO, A. J. V.; CARVAlHO, A. G.; DAMÁSIO, R. A. P.; OLIVEIRA, B. S.; CARNEIRO, A. C. O.; COLODETTE, J. L. Relationship between the anatomy and drying in Eucalyptus grandis $\mathrm{x}$ Eucalyptus urophylla wood. Revista Árvore, Viçosa, v. 40, n. 4, p. 723-729, 2016.

ZANUNCIO, A. J. V.; LIMA, J. T.; MONTEIRO, T. C.; CARVALHO, A. G.; TRUGILHO, P. F. Secagem de toras de Eucalyptus e Corymbia para uso energético. Scientia Forestalis, Piracicaba, v. 41, n. 99, p. 353-360, 2013. 